\title{
Why Does the American Constitution Lack Social and Economic Guarantees?
}

\section{Citation}

Cass R. Sunstein, Why Does the American Constitution Lack Social and Economic Guarantees? (Public Law \& Legal Theory Working Papers No. 36, 2003).

\section{Published Version}

http://chicagounbound.uchicago.edu/public_law_and_legal_theory/385/

\section{Permanent link}

http://nrs.harvard.edu/urn-3:HUL.InstRepos:12921741

\section{Terms of Use}

This article was downloaded from Harvard University's DASH repository, and is made available under the terms and conditions applicable to Other Posted Material, as set forth at http:// nrs.harvard.edu/urn-3:HUL.InstRepos:dash.current.terms-of-use\#LAA

\section{Share Your Story}

The Harvard community has made this article openly available.

Please share how this access benefits you. Submit a story.

Accessibility 


\section{University of Chicago Law School Chicago Unbound}

2003

\section{Why Does the American Constitution Lack Social and Economic Guarantees?}

Cass R. Sunstein

Follow this and additional works at: http://chicagounbound.uchicago.edu/ public_law_and_legal_theory

Part of the Law Commons

\section{Recommended Citation}

Cass R. Sunstein, "Why Does the American Constitution Lack Social and Economic Guarantees?" (Public Law \& Legal Theory Working Papers No. 36, 2003).

This Working Paper is brought to you for free and open access by the Working Papers at Chicago Unbound. It has been accepted for inclusion in Public Law and Legal Theory Working Papers by an authorized administrator of Chicago Unbound. For more information, please contact unbound@law.uchicago.edu. 


\title{
CHICAGO
}

Public Law and Legal Theory Working Paper No. 36

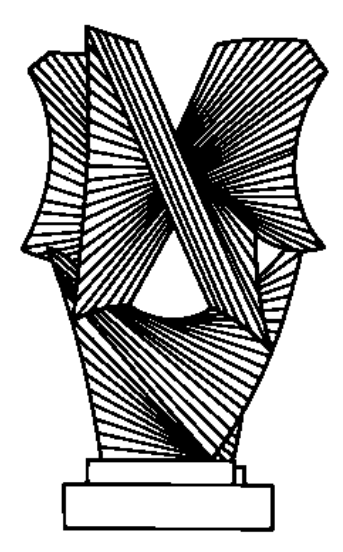

\section{Why DOES THE AMERICAN CONSTITUTION LACK SOCIAL AND ECONOMIC GUARANTEES?}

\author{
Cass R. Sunstein \\ THE LAW SCHOOL \\ THE UNIVERSITY OF CHICAGO
}

January 2003

This paper can be downloaded without charge at http://www.law.uchicago.edu/academics/publiclaw/index.html and at The Social Science Research Network Electronic Paper Collection: http://ssrn.com/abstract_id=375622 


\title{
Preliminary draft 01/02/03 \\ All rights reserved
}

\section{Why Does the American Constitution Lack Social and Economic Guarantees?}

\author{
Cass R. Sunstein
}

\begin{abstract}
Why does the American Constitution lack contain social and economic guarantees, which appear in most contemporary constitutions? This essay explores four possible answers: chronological, cultural, institutional, and realist. The chronological explanation emphasizes the fact that in the late eighteenth century, social and economic rights simply were not on the viewscreen for constitution-makers. The point is correct, but as a complete account, the chronological explanation fails for the simple reason that constitutional meaning changes over time. The institutional explanation emphasizes that Americans typically see constitutional rights not as mere goals or aspirations, but as pragmatic instruments for judicial enforcement. The difficulty with the institutional explanation is that social and economic rights can, in fact, be enforced judicially. The cultural explanation sees the absence of social and economic rights as part of the general failure of socialist movements in the United States ("American exceptionalism"). The problem with this explanation is that social and economic rights can in fact coexist with a market economy. The realist explanation places a spotlight on the underappreciated fact that the United States Supreme Court came very close, in the 1960s and 1970s, to recognizing social and economic rights under the Constitution. The Court's refusal to recognize such rights was largely a result of the presidential election of 1968 and in particular of four critical appointments by President Nixon. This is an important source of "American exceptionalism" in the domain of social and economic rights. Here as elsewhere, there is a possibility of multiple equilibria, and with a small difference or two, the United States might well have had an equilibrium that included social and economic rights.
\end{abstract}

"The alms given to a naked man in the street do not fulfill the obligations of the state, which owes to every citizen a certain subsistence, a proper nourishment, convenient clothing, and a kind of life not incompatible with health."

Montesquieu

"This Republic had its beginning, and grew to its present strength, under the protection of certain inalienable rights - among them the right of free speech, free press, free worship, trial by jury, freedom from unreasonable searches. They were our rights to life and liberty.

\footnotetext{
* Karl N. Llewellyn Distinguished Service Professor of Jurisprudence, Law School and Department of Political Science, University of Chicago.
} 
As our economy has grown in size and stature, however-as our industrial economy expanded - these political rights proved inadequate to assure us equality in the pursuit of happiness. ... We have accepted, so to speak, a second Bill of Rights under which a new basis of security and prosperity can be established for all-regardless of station, race, or creed, the Nation;

The right to a useful and remunerative job in the industries or shops or farms or mines of

The right to earn enough to provide adequate food and clothing and recreation;

The right of every farmer to raise and sell his products at a return which will give him and his family a decent living;

The right of every businessman, large and small, to trade in an atmosphere of freedom from unfair competition and domination by monopolies at home or abroad;

The right of every family to a decent home;

The right to adequate medical care and the opportunity to achieve and enjoy good health;

The right to adequate protection from the economic fears of old age, sickness, accident, and unemployment;

The right to a good education.

I ask Congress to explore the means for implementing this economic bill of rights - for it is definitely the responsibility of the Congress to do so."

\section{Franklin Delano Roosevelt}

\section{Introduction}

The Universal Declaration of Human Rights protects a wide range of social and economic rights. It proclaims, for example, that "Everyone has a right to work, to free choice of employment, to just and favourable conditions of work and to protection against unemployment." It also provides a "right to equal pay for equal work," a right "to form and to join trade unions for protection," and a right to "just and favourable remuneration ensuring for himself and his family an existence worthy of human dignity, and supplemented, if necessary, by other means of social protection." More broadly still, the Declaration gives "everyone" a "right to a standard of living adequate for the health and well-being of himself and his family, including food, clothing, housing and medical care and necessary social services, and the right to security in the event of unemployment, sickness, disability, widowhood, old age or other lack of livelihood in circumstances beyond his control." The Declaration also provides a "right to education" and to "social security." 
Many modern constitutions follow the Declaration in creating social and economic rights. They guarantee citizens a wide range of social entitlements. Of course this was true for the Soviet Constitution. But many non-communist and post-communist constitutions contain these rights as well. The Romanian Constitution, for example, includes the right to leisure, the right to work, the right to equal pay for equal work, and measures for the protection and safety of workers. The Syrian Constitution proclaims that the "state undertakes to provide work for all citizens." The Constitution of Norway imposes on the state the responsibility "to create conditions enabling every person capable of work to earn a living by his work." "The Bulgarian Constitution offers the right to a holiday, the right to work, the right to labor safety, the right to social security, and the right to free medical care. The Hungarian Constitution proclaims, "People living within the territory of the Republic of Hungary have the right to the highest possible level of physical health." It also provides that "Everyone who works has the right to emolument that corresponds to the amount and quality of the work performed." The Constitution of Peru announces, "The worker is entitled to a fair and adequate remuneration enabling him to provide for himself and his family material and spiritual well-being."2

Not every modern constitution creates rights of this sort; such rights are entirely absent from a number of contemporary constitutions. Indeed some nations recognize such rights, but in a way that seems to make them goals and not rights at all. The Constitution of Switzerland, for example, says that "the Confederation and the cantons seek to ensure" certain rights, involving social security, necessary health care, and more. ${ }^{3}$ The Constitution of India offers a range of civil and political rights, and also offers "directive principles of state policy," saying that the state shall "direct its policy towards securing" certain rights, including an adequate means of livelihood, equal pay for equal work for both men and women, and more. ${ }^{4}$ This strategy is taken as well in Ireland, Nigeria, and Papua New Guinea. The South African Constitution recognizes a wide range of social and economic rights, but also acknowledges resource constraints, typically obliging the state to "take reasonable legislative and other measures, within its available resources, to achieve the progressive realisation of" the relevant right. ${ }^{5}$ Provisions of this kind are ambiguous, but they have been held to be justiciable, obliging the government not to default in its basic obligation. ${ }^{6}$

I am concerned here with a particular puzzle. The constitutions of most nations create social and economic rights, whether or not they are enforceable. But the American Constitution does nothing of the kind. Why is this? What makes the American Constitution so distinctive in this regard?

I will explore four possible answers here. In the process I hope to cast some light on the effects of constitutions, cultural differences, and social and economic guarantees in

\footnotetext{
${ }^{1}$ Constitution of Norway, Article 110.

${ }^{2}$ Constitution of Peru, Article 24.

${ }^{3}$ Article 41.

${ }^{4}$ Constitution of India, Part IV, art. 39.

${ }^{5}$ See, e.g., section 26 (housing).

${ }^{6}$ See Grootboom.
} 
general. The first explanation is chronological; it points simply to the age of the American Constitution, which is the oldest in force in the world. The second, institutional in nature, emphasizes that social and economic right cannot easily coexist with judicial review, a preoccupation of the American legal culture. The third points to "American exceptionalism" as it is standardly understood: the absence of a significant socialist movement in the United States. The fourth, rooted in legal realism, stresses developments within the United States Supreme Court in the 1960s and 1970s. In the end my major suggestion will be that the fourth explanation is the most interesting and even correct. The Constitution means what the Supreme Court says that it means, and with a modest shift in personnel, the Constitution would have been understood to create social and economic rights of the sort recognized in many modern constitutions, and indeed in the constitutions of some of the American states.

An additional word before we proceed: To evaluate the four explanations, it is important to distinguish between necessary and sufficient conditions for the recognition of social and economic rights. Judicial interpretation of an ambiguous constitutional provision is a sufficient condition, though not a necessary one. Ratification of an explicit provision is a sufficient condition, though not a necessary one. I am concerned here to explore both the failure of a serious ratification effort and the absence of a judicial interpretation that would recognize social and economic rights.

This essay is organized as follows. Part II offers some conceptual preliminaries. My goal here is to challenge the claim of a sharp dichotomy between traditional constitutional rights and social and economic rights, by showing that both of these depend on an active government and indeed on the expenditure of taxpayer funds. Part III explores the chronological explanation. Part IV briefly discusses the amendment process and also the New Deal period, in which social and economic guarantees received prominent public attention. Part V examines institutional considerations. Part VI investigates the cultural explanation. Part VII explores developments in the 1960s and 1970s, suggesting that the Court came to close to understanding the Constitution to create social and economic rights, and that with slight differences in personnel, the Court would have done exactly that. Part VIII is a brief conclusion.

\section{Conceptual Preliminaries}

What is distinctive about social and economic rights? What makes them unusual? The conventional answer is that while ordinary rights create "negative" checks on government, preserving a sphere of private immunity, social and economic rights impose "positive" obligations on government, creating a set of private entitlements to government assistance. On this view, negative guarantees are both time-honored and consistent with the (classical) liberal tradition. Positive rights are novel, a creation of the New Deal, social democracy, or perhaps socialism, assimilating to the category of "rights" what would otherwise be seen as pleas for public assistance. In a standard formulation, Roosevelt's proposed Second Bill of Rights, set out as above, is distinctive "in linking together the 
negative liberty from government achieved in the old Bill of Rights to the positive liberty through government to be achieved in the new Bill of Rights."7

This is indeed a conventional way to see matters, and it has some historical support. Social and economic guarantees, often described as "second generation" rights, did receive recognition long after the traditional liberal rights. But the conventional understanding is a bad way of understanding the relevant categories. Most of the so-called negative rights require government assistance, not governmental abstinence. Those rights cannot exist without public assistance. Consider, for example, the right to private property. As Bentham wrote "property and law are born together and die together. Before the laws there was no property; take away the laws, all property ceases." In the state of nature, private property cannot exist, at least not in the way that it exists in a free society. In the state of nature, any property "rights" must be protected either through self-help - useful to the strong, not to the weak-or through social norms. This form of protection is far too fragile to support a market economy or indeed the basic independence of citizens. As we know it, private property is both created and protected by law; it requires extensive governmental assistance.

The same point holds for the other foundation of a market economy, the close sibling of private property: freedom of contract. For that form of freedom to exist, it is extremely important to have reliable enforcement mechanisms in the form of civil courts. The creation of such mechanisms requires action, not abstinence. Nor is the point - the dependence of rights on public assistance-limited to the foundations of a market economy. Take, for example, the right to be free from torture and abuse, perhaps the defining "negative" freedom. Of course it is possible to say this right is a "negative" safeguard against public intrusion into the private domain. But as a practical matter, this right requires a state apparatus willing to ferret out and to punish the relevant rights violations. If the right includes protection against private depredations, it cannot exist simply with government abstinence. If the right is limited to protection against public abuse of power, it can be satisfied by abstinence; but in practice, abstinence from torture and abuse must be guaranteed by a public apparatus that will deter and punish misconduct. Some rights require government to protect against its own rights violations. If we go down the list of conventional private rights, we will see this same point at every turn.

There is a larger implication, with direct relevance to the question of social and economic rights. All constitutional rights have budgetary implications; all constitutional rights cost money. ${ }^{8}$ If the government plans to protect private property, it will have to expend resources to ensure against both private and public intrusions. If the government wants to protect people against unreasonable searches and seizures, it will have to expend resources to train, monitor, and discipline the police. If the government wants to protect freedom of speech, it must, at a minimum, take steps to constrain its own agents; and these steps will be costly. It follows that insofar as they are costly, social and economic rights are not unique.

\footnotetext{
${ }^{7}$ Doris Kearns Goodwin, No Ordinary Time 485 (1994).

${ }^{8}$ This is the theme of Stephen Holmes and Cass R. Sunstein, The Cost of Rights (1999).
} 
Now it is possible that such rights are unusually costly - that to ensure (for example) that everyone has housing, it will be necessary to spend more than must be spent to ensure (for example) that everyone is free from unreasonable searches and seizures. But any such comparisons are empirical and contingent; they cannot be made on an a priori basis. We could imagine a society in which it cost a great deal to protect private property, but not so much to ensure basic subsistence. Of course most societies are not like that; in most societies, the management of a social welfare system is more expensive than the management of a system to protect property rights. This kind of distinction-quantitative rather than qualitative in nature - is probably the central one.

\section{Chronology}

\section{A. The First Generation of Framers and the First Generation of Rights}

In explaining the absence of social and economic guarantees from the American Constitution, the most natural point is chronological. The simple claim is that the American Constitution, the oldest existing constitution in the world, was ratified during the last eighteenth century - a time when constitutions were simply not thought to include social and economic guarantees. ${ }^{9}$ The American framers were building on rights as understood in the British tradition. No one then suggested, or even thought to suggest, that the Bill of Rights should contain a guarantee of this kind. When it was drawn up, the American approach was entirely standard, and hence the absence of social and economic rights is simply a matter of timing. On this view, there was no American exceptionalism, and there is really no puzzle to be solved. When modern constitutions were drawn up, the international understanding was altogether different, and hence it is entirely to be expected that social and economic rights will be found in the constitutions of (for example) Bulgaria, South Africa, Norway, and Russia. Whether a constitution contains secondgeneration rights can be predicted pretty well just by looking at the year of its ratification. With respect to such rights at the constitutional level, American exceptionalism is a myth and an illusion.

\section{B. The Second Generation In the First: Principle}

To emphasize the chronological point is emphatically not to suggest that the American framers did not care about poor people. On the contrary, some of their writing suggested a strong commitment to social and economic rights, though not at the constitutional level. James Madison, probably the most influential voice in the founding period, offered the following means of combating "the evil of parties": "1. By establishing a political equality among all. 2. By withholding unnecessary opportunities from a few, to increase the inequality of property, by an immoderate, and especially an unmerited, accumulation of riches. 3. By the silent operation of laws, which, without violating the rights of property, reduce extreme wealth to a state of mediocrity, and raise extreme indigence toward a state of comfort." ${ }^{\prime \prime}$ Jefferson, not a framer but a strong influence

\footnotetext{
${ }^{9}$ Of course this point itself remains to be explained. But any such explanation would not involve American exceptionalism of any sort, which is my concern here.

${ }^{10}$ James Madison, 14 The Papers of James Madison 197-98 (1983).
} 
during the founding period, wrote, "I am conscious that an equal division of property is impracticable. But the consequences of this enormous inequality producing so much misery to the bulk of mankind, legislatures cannot invest too many devices for subdividing property, only taking care to let their subdivisions go hand in hand with the natural affections of the human mind. ... . Another means of silently lessening the inequality of property is to exempt all from taxation below a certain point, and to tax the higher portions of property in geometrical progression as they rise. Whenever there is in any country, uncultivated lands and unemployed poor, it is clear that the laws of property have been so far extended as to violate natural right. The earth is given as a common stock for man to labor and live on."11

It is relevant here that many of the classical liberal thinkers, far from rejecting social and economic rights, explicitly endorsed them. Recall Montesquieu's claim, quoted above: "The alms given to a naked man in the street do not fulfill the obligations of the state, which owes to every citizen a certain subsistence, a proper nourishment, convenient clothing, and a kind of life not incompatible with health.” John Locke of course a large influence on American political thought, and he wrote in similar terms: "As Justice gives every Man a Title to the product of his honest Industry, and the fair Acquisitions of his Ancestors descended to him, so Charity gives every man a Title to so much of another's plenty, as will keep him from extream want, where he has no means to subsist otherwise."

The chronological account, in short, emphasizes that some of the Constitution's framers believed in some sort of social and economic rights, but adds that they did not believe in placing those rights in a constitution, for the simple reason that constitutionalization of such rights was a most foreign concept at the time. Of course it would remain necessary to explain the reason for the rise of second-generation rightswhy they were absent when they were absent, and why they arose when they did - but this would not be a question about American exceptionalism in particular. It would be a question about changing conceptions of constitutional rights over time.

\section{A Problem}

Undoubtedly the chronological account has considerable truth. But as a complete explanation, it faces a serious problem: The meaning of the Constitution changes over time, and in numerous ways, the American constitution has gone far beyond the original understanding of its authors and ratifiers. Constitutional change is in part a function of explicit constitutional amendments, and this is the place to begin. After the Civil War, the Constitution was of course significantly altered, and here too we find no serious interest in social and economic rights. Why not? Perhaps the same chronological account works here as well: In the late nineteenth century, social and economic rights were generally unfamiliar. But in the New Deal period (on which more shortly), the Constitution was not amended at all; there was no interest in adding such rights to the Constitution. Why not? In the midst of President Johnson's Great Society, and during widespread late-twentieth interest in poverty, housing rights, and the like, America saw no serious debate about constitutional amendments. There was no significant discussion of adding social and

\footnotetext{
${ }^{11}$ Thomas Jefferson, 8 The Papers of Thomas Jefferson 681-83 (1953).
} 
economic rights to the American constitution. The chronological account cannot explain this fact.

There is another problem. Constitutional change is often a product not of constitutional amendment, but of interpretation, leading to new understandings of old provisions. ${ }^{12}$ Even if the eighteenth century constitution did not contain social and economic rights, the American constitution might well have interpreted to do so. Consider the question whether there is a problem of "American exceptionalism" in the absence of a ban on sex discrimination in the American constitution. Almost all contemporary constitutions explicitly ban sex discrimination; why is the American constitution so different? A chronological account offers part of an answer, but it is ludicrously incomplete. The Equal Rights Amendment might have been ratified. It wasn't; why not? Part of the answer points not to American exceptionalism in the context of sex equality, but to the change in judicial interpretation of the equal protection clause over time. The American constitution is now understood to have something very much like a constitutional ban on sex discrimination, not because of the original understanding of its text, but because of new judicial interpretations. If this has happened in the context of sex equality, why hasn't it happened for social and economic rights as well? The chronological account offers no answer.

\section{Detour: Amendments and The New Deal}

\section{A. Procedural Difficulties}

The chronological account can be strengthened by emphasizing a simple fact: It is not easy to amend the American Constitution, even if there is wide support for the amendment. The Constitution nearly locks out changes - not by making them impossible, but by making them extremely difficult. The American public broadly supported the Equal Rights Amendment, but it nonetheless failed to pass. Because the Constitution creates real obstacles to amendment, immense popular support was not enough to ensure ratification of the ERA. Even if social and economic rights commanded widespread popular support, they might not find their way into the constitution.

By itself this point seems a weak explanation of the failure to create social and economic rights, because no serious amendment effort was made. In these circumstances, it might seem that the difficulty of amending the constitution cannot explain the situation. But the absence of a serious amendment effort should not be misinterpreted. The very difficulty of amending the Constitution has a strong deterrent effect, and perhaps such an effort would have been made with a different constitutional structure. Because it is difficult to speculate about counterfactual history, the possibility cannot be ruled out. But there is every reason to think that even with a much easier amendment process, the Constitution would not have been altered to provide social and economic guarantees.

\footnotetext{
${ }^{12}$ See David Strauss, Common Law Constitutional Interpretation, 63 U Chi L Rev 877 (1996).
} 


\section{B. Second Generation Rights in the New Deal}

The point can be clarified by reference to the New Deal era. This was the period in which the United States thought most seriously about social and economic guarantees - not with an eye toward constitutional amendments, but nonetheless in a serious and selfconscious manner. Indeed, the New Deal saw a large-scale renovation of the American constitutional structure, amounting to a kind of second American Revolution. ${ }^{13}$ The renovation involved the three cornerstones of that structure: federalism; checks and balances; and individual rights. As is well known, the powers of the national government significantly increased, and a great deal of authority was concentrated in the presidency. What is less well known is the nature of the New Deal's renovation of preexisting understandings of legal rights. Before the New Deal, the American legal culture defined "rights" largely in terms of the eighteenth century catalogue of the common law, and hence freedom of contract and private property were prominent illustrations of rights protected from governmental incursion.

The New Dealers believed that the common law catalogue included too much and too little. A large part of their argument was an effort to denaturalize the common law. In their view, rights of freedom of contract and private property depended for their existence on a legal apparatus; they were hardly natural, but resulted from a form of governmental intervention into private affairs. Thus Roosevelt urged, "We must lay hold of the fact that the laws of economics are not made by nature. They are made by human beings." This claim did not mean that freedom of contract and private property were bad ideas. But it did mean that they should be evaluated pragmatically and in terms of what they did for or to the human beings subject to them. And on this count, the New Dealers supported many readjustments of common law interests. Rights to governmental protection within the employment market, for example, were insufficiently protected by the common law, as were the interests of the poor, consumers of dangerous food and drugs, the elderly, traders on securities markets, and victims of unfair trade practices.

This basic theme, the central ingredient of New Deal constitutionalism, was prominent throughout Roosevelt's presidency. In his speech accepting the Democratic nomination for the presidency in 1936, for example, Roosevelt argued that although the constitutional framers were concerned only with political rights, new circumstances required the recognition of economic rights as well, because "freedom is no half-and-half affair." The most dramatic statement of this revised notion of entitlement came in President Roosevelt's State of the Union address of 1944, which set forth the "Second Bill of Rights" quoted as the epigraph to this essay.

In coming to terms with Roosevelt's proposal, three points are worth emphasizing. The first is the sheer amplitude of the relevant rights, including most of what can be found in the Universal Declaration and in contemporary constitutions. The second is Roosevelt's insistence that the relevant rights had already been "accepted," post-New Deal - that they reflected the nation's official creed in 1944, and hence represent no new innovation. The third is that Roosevelt proposed no constitutional amendment, and no judicial role, but

\footnotetext{
${ }^{13}$ Or perhaps third if we include the Civil War Amendments.
} 
instead an effort by Congress to "explore the means for implementing this economic bill of rights." It should be noted in this regard that at the state level, constitutional amendments were indeed ratified, endorsing aspects of the Second Bill of Rights as a matter of state constitutional law. Indeed, about a dozen states now offer social and economic rights. The New York Constitution is exemplary: "The aid, care, and support of the needy are public concerns and shall be provided by the state and by such of its subdivisions, and in such manner, and by such means, as the legislature may from time to time determine." The claim of large-scale American exceptionalism as a cultural matter is complicated not only by Roosevelt's plea for a Second Bill of Rights, but also by the existence of considerable constitutional innovation at the state level - activity that has not, by the way, made much differences in terms of actual lives of poor people.

But for present purposes, the crucial point is that the New Dealers did not pursue constitutional reform. Their approach on this count is fully consistent with their general strategy, which was to avoid official amendments entirely, and to use political processes and constitutional interpretation to move in the directions that they sought. ${ }^{14}$ Part of the reason for this strategy was the sheer difficulty of producing constitutional amendments. Part of it was great suspicion of the conservative judiciary. For those interested in creating a second Bill of Rights, constitutional amendment did not seem an attractive option in light of the inevitable fact that any such amendment would increase the authority of judges. The point is directly related to the second explanation, to which I now turn.

\section{Constitutions As Pragmatic Instruments}

The institutional explanation claims that in the American culture, constitutions are seen as pragmatic instruments - suited for, and not inextricable from, judicial enforcement. And indeed it is useful, even crucial to distinguish between the pragmatic and the aspirational conception of constitutions. When presented with a proposed constitutional provision, many Americans tend to ask, "What will this provision do, in fact? How will courts interpret this provision, in fact?"

These questions played a major role in debates over the Equal Rights Amendment- - helping to raise qualms about that Amendment even for those committed to sex equality. ${ }^{15}$ But other people, especially but not only in Eastern Europe, tend to think of constitutions as literally declarative - as expressive of a nation's deepest hopes and highest aspirations. They like to ask, "what values does this provision affirm, in principle?" They see a constitution as a kind of declaration, probably not meant for judicial enforcement, and possibly not meant for compliance in the real world. As analogies, consider the Declaration of Independence or even the Universal Declaration of Human Rights, which was debated and signed with little attention to the question of judicial enforcement, which was of course not contemplated. It is important to emphasize here that many of the constitutions containing social and economic rights simply borrowed from the Universal Declaration. It is also important to note that there is real doubt about whether the many constitutions containing social and economic rights have made any difference at all "on the

\footnotetext{
${ }^{14}$ See Bruce A. Ackerman, We the People vol. 1 (1995.

${ }^{15}$ See Jane Mansbridge, Why We Lost the ERA (1994).
} 
ground"- that is, there is real doubt about whether such rights have actually lead to more money, food, or shelter for poor people.

If we take the pragmatic approach, we will be likely to ask whether social and economic rights would be a sensible part of an enforceable constitution containing the important institution of judicial review. Should a constitution create a "right to just and favourable remuneration"? To "a standard of living adequate for the health and leisure of" one's family, "including food, clothing, housing and medical care and necessary social services"? To "rest and leisure"? What would these provisions mean, concretely? What would they mean in a poor nation with high levels of unemployment and inadequate medical care and housing? What would they mean, concretely, in a wealthy nation like the United States or France? If a nation failed to protect the relevant rights, would courts be authorized to intervene - as they usually are when rights are violated?

If these questions appear difficult to answer, we might explain American exceptionalism in institutional terms, as a response to the conception of constitutional rights as pragmatic instruments. And we might explain the contemporary practice of including such rights, all over the world, as a product of an understanding that they need not mean much, if anything in practice. Such rights are meant as signals, domestically and internationally, but they are not legally enforceable instruments. On this view, Americans should not be thought skeptical of social and economic guarantees in principle; even Ronald Reagan was committed to a social safety net. The real source of skepticism is an account of what kind of document a constitution really is, and of what kinds of rights belong in a document of that sort.

There is considerable truth in this explanation. American courts have been reluctant to recognize social and economic rights in part because of a belief that enforcement and protection of such rights would strain judicial capacities. Political actors, even those interested in helping poor people, have been skeptical about the likely effectiveness of constitutional provisions that might be ignored in practice. Outside of the United States, some nations, including India and South Africa, have been alert to the underlying difficulties, and have sharply limited the constitutional status of such rights by reducing judicial authority. And as I have noted, social and economic rights have served as aspirations, with apparently no real-world effects, in the many nations in which they are recognized. It is hard to show that when nations are relatively more likely to help poor people, it is because they have constitutional provisions calling for such help.

But the institutional account cannot be all of the picture. The reason is that those who want constitutions to be pragmatic instruments need not reject the idea of social and economic rights. In the United States itself, state constitutions protect those rights, and some courts are willing to enforce them, at least to some degree. ${ }^{16}$ In South Africa, initial steps have been taken, not toward careful judicial oversight of the welfare system, and not toward ensuring that everyone has decent shelter and food, but toward ensuring that the government at least creates "programs" that ensure minimal attention to basic needs. ${ }^{17}$ It is

\footnotetext{
${ }^{16}$ See Tucker v. Toia.

${ }^{17}$ Grootboom.
} 
surely right to say that social and economic rights could strain judicial capacities. Certainly no court, in poor or rich nations, is going to be able to ensure that everyone has decent food, clothing, medical care, and housing. ${ }^{18}$ But those who are committed to such rights, in principle, might well urge that courts could take steps to ensure that basic needs receive a degree of legislative priority, and that conspicuous neglect would be corrected. As a result, the institutional explanation has a serious defect.

\section{The Cultural Explanation}

I now turn to what may well be the most tempting explanation, one that points to American exceptionalism in general. Socialism has never been a powerful force within the United States. America is said to be exceptional because "it didn't happen here" ${ }^{\text {"19 }}$ : There was never a strong effort to move the United States in the direction of socialism or social democracy. On this view, the absence of social and economic rights has an explanation in terms of American politics or even culture. No group that might have been interested in such rights was ever powerful enough to obtain them. In the debate over the Universal Declaration, social and communist nations were most enthusiastic about social and economic guarantees, whereas capitalist nations were most skeptical. Perhaps this, in a nutshell, is the best explanation for the American Constitution's failure to include such guarantees. The Constitution's content is a political artifact, and American politics is simply different.

There is of course an extensive literature on American exceptionalism in general, with many competing views. Some people suggest that American workers have had, or have thought that they have, a high degree of upward mobility, muting dissatisfaction with any particular status quo. Others have suggested that feudalism is a necessary precursor for socialism, and that because America lacks a feudal past, socialism was inevitably going to fail. Others suggest that the American electoral system, with two dominant parties and elaborate checks and balances, dampened socialist efforts in the period in which they succeeded elsewhere. Still others suggest that powerful private groups were quick to suppress socialist movements whenever they threatened to be effective. For present purposes, it is unnecessary to choose among these competing explanations. What matters is the underlying weakness of socialism in the United States.

There is this much truth in the cultural explanation: The existence of social and economic rights, within a nation's constitution, is strongly correlated ${ }^{20}$ with the strength of socialist or left-wing elements within that nation. In America, a strong socialist movement might well have sought a constitutional amendment or instead led to political changes that would have produced novel interpretations. As we shall see, a more left-wing political order would have produced a more left-wing Supreme Court, and such a court would likely have interpreted the Constitution to recognize social and economic rights (see below). For this reason it is right to say that to understand the absence of such rights from American

\footnotetext{
${ }^{18}$ Compare first generation rights, which are not very different on this count. The fourth amendment, for example, is violated every day.

${ }^{19}$ See Lipset; Foner.

${ }^{20}$ But far from perfectly.
} 
constitutional law, it is helpful to say something about the absence of a significant socialist movement in the United States. But as a full account of the situation, the cultural explanation is plainly inadequate. The reason is that a strong socialist movement is neither a necessary nor a sufficient condition for social and economic rights. It is easy to imagine a nation in which such a movement exists, but does not think it useful to insist on constitutional provisions of this kind. Consider Canada, Israel, and England, three nations with strong socialist movements but without social and economic rights.

It is also easy to imagine a nation without a strong socialist movement but with considerable enthusiasm for social and economic rights. Indeed several such nations exist. Franklin Delano Roosevelt was no socialist, indeed he strongly believed in capitalist institutions; but he was committed to "freedom from want," and as we have seen, he sought congressional protection of that form of freedom. It is easy to imagine a somewhat different FDR, one who had the same set of substantive beliefs, but who also believed that the constitutional route was the correct one to take. Why was that FDR not America's FDR? The reason does not lie in the absence of a strong socialist movement in the United States. If an American president could be committed to a second bill of rights for legislative enactment, he could also be committed to a second bill of rights at the constitutional level. The absence of significant American interest in constitutionalization is not about culture alone. It must involve, at a minimum, the institutional points mentioned above.

\section{The Realist Explanation}

I have emphasized that the meaning of the American Constitution changes because of new interpretations. If the Constitution meant, in all respects, what it originally meant, American constitutional rights would be thin indeed. Most of the key rights-protecting provisions now mean far more than they originally meant. For example, no provision of the Constitution forbids the national government from discriminating on the basis of race; but the fifth amendment, preventing denials of liberty without due process of law, is now taken to prohibit race discrimination at the national level. The best reading of history is that the first amendment allowed Congress to regulate a great deal of speech; judicial interpretation, especially in the late twentieth century, has lead to a robust free speech principle, far beyond anything envisaged by the first amendment's authors and ratifiers. I have mentioned that the fourteenth amendment, when originally ratified, did not prohibit sex discrimination at all, but the American Constitution is now understand to ban most forms of sex discrimination, and indeed to contain a far more robust ban than can be found under most of the world's constitutions that contain explicit bans on sex discrimination.

If the American Constitution meant what it originally meant, the nation would have a lot of explaining to do - and the absence of social and economic rights would be one of the least conspicuous forms of American exceptionalism at the constitutional level. Here is a hypothesis: An interpretation of the fourteenth amendment that called for social and economic rights would not, in fact, be much more of a stretch of the document than many interpretations that are now taken for granted in American constitutional law. I cannot defend the hypothesis here; to do so, it would be necessary to say a great deal about what 
constitutional interpretation entails. But I believe that I am building on conventional understandings.

All this is relatively abstract. The realist explanation for American practice is more concrete. It emphasizes that American constitutional law is, to a considerable degree, a form of common law, ${ }^{21}$ based on analogical reasoning. It suggests that American constitutional law could easily have come to recognize social and economic rights. It urges that the crucial development was the election of President Nixon in 1968, which produced four Supreme Court appointments, which lead in turn to a critical mass of justices willing to reject the claim that social and economic rights were part of the Constitution. So described, the realist explanation seems to me entirely correct.

To understand the point, it is necessary to see that there was a serious and partially successful effort, in the 1960s and 1970s, to understand the Constitution to create social and economic guarantees. In some of the cases, the Court went so far as to hold that the government must subsidize poor people in certain domains. In Griffin v. Illinois, ${ }^{22}$ for example, the Court held that the equal protection clause requires states to provide trial transcripts or their equivalent to poor people appealing their criminal convictions. In Douglas v. California, ${ }^{23}$ the Court extended this ruling, concluding that poor people must be provided with counsel on their first appeal of a criminal conviction. When the Court struck down the poll tax, ${ }^{24}$ it effectively ruled that states must provide the vote free of charge- even though it is expensive to run an election.

These decisions emphatically recognize social and economic rights; they say that the government must provide financial assistance to poor people in certain domains. For this reason it is too simple to say that the American Constitution is not understood to create social and economic rights. But the reach of these decisions is limited to contexts in which poverty interacts with interests that seem part and parcel of citizenship (the rights to vote and to contest a criminal conviction). In other cases, however, the Court went further. In Shapiro v. Thompson, ${ }^{25}$ the Court held that the state of California could not, consistently with the Constitution, impose a six-month waiting period before new arrivals to the state could receive welfare benefits. The Court relied on the constitutional right to travel, but it also spoke of the special needs for people, contending that California denies "welfare aid upon which may depend the ability of the families to obtain the very means to subsist food, shelter, and other necessities of life." If the right to travel was all that was involved, this suggestion would seem purposeless.

Indeed, the Court came to give procedural protection to welfare benefits, in the important sense that under the due process clause, the government is not permitted to remove those benefits without giving people a hearing. ${ }^{26}$ In its initial decision, the Court

\footnotetext{
${ }^{21}$ See Strauss, supra note.

${ }^{22} 351$ U.S. 12 (1956).

${ }^{23} 372$ U.S. $353(1963)$.

${ }^{24}$ Harper v. Virginia Bd. of Elections, 383 U.S. 663 (1966).

${ }^{25} 394$ U.S. 618 (1969).

${ }^{26}$ Goldberg v. Kelly.
} 
emphasized the particular nature of welfare benefits: "Welfare, by meeting the basic demands of subsistence, can help bring within the reach of the poor the same opportunities that are available to others to participate meaningfully in the life of the community. [Public] assistance, then, is not mere charity, but a means to "promote the general Welfare, and secure the Blessings of Liberty to ourselves and our Posterity." With its striking reference to the Constitution itself, the Court seemed to signal its willingness to consider the possibility that some constitutional provision would grant a right to subsistence for those in need. In fact prominent academic writing suggested that the Court was moving in that direction. ${ }^{27}$

By 1970, it was not at all clear that the Court would not eventually recognize a robust set of social and economic rights. In retrospect, the crucial event was the election of President Nixon in 1968, and his four appointments to the Court: Warren Burger in 1969, Harry Blackmun in 1970, and Lewis Powell and William Rehnquist in 1972. These appointees proved decisive to a series of decisions, issued in rapid succession, limiting the reach of Warren Court decisions and eventually making clear that social and economic rights do not have constitutional status outside of certain restricted domains. During the period from 1970 to 1973, the Court cut off the emerging development. Here is a brief outline.

In Dandridge v. Williams, ${ }^{28}$ the Court rejected a constitutional challenge to a state law that imposed an upper limit on the size of grants under its welfare program, regardless of the size of the family. The Court recognized that pressing necessities were involved, but found that fact constitutionally irrelevant, and said so explicitly. In Lindsay v. Normet, ${ }^{29}$ the Court upheld a state's summary eviction procedure. The plaintiff contended that the "need for decent shelter" and the "right to retain peaceful possession of one's home" were fundamental interests under the Constitution, subject to intrusion only after a powerful showing of countervailing government justification. The Court rejected the argument, saying that the "Constitution does not provide judicial remedies for every social and economic ill. We are unable to perceive in that document any constitutional guarantee of access to dwellings of a particular quality." Justice Powell wrote the key decision for a 5-4 majority in San Antonio School District v. Rodriguez, ${ }^{30}$ which upheld a constitutional challenge to local financing of public schools, even though local financing produces large intrastate disparities in per-pupil expenditures. Justice Powell's lengthy opinion understood previous cases in an exceedingly narrow way, as involving absolute deprivations of constitutionally protected interests. Rodriguez was effectively the death knell for social and economic rights in the United States.

This overview should be sufficient to show that the brief period from 1970 through 1973 played a crucial and underappreciated role in American jurisprudence. The Nixon nominees rejected what appeared to be an emerging trend in the direction of recognizing a robust set of social and economic rights. There can be no serious doubt that Humphrey

\footnotetext{
${ }^{27}$ See Frank Michelman, On Protecting the Poor Through the Fourteenth Amendment.

${ }^{28} 397$ US 471 (1970).

${ }^{29} 405$ US 56 (1972).

${ }^{30} 411$ US 1 (1973).
} 
nominees would have seen things very differently. Of course we cannot know what the Court would ultimately have said, nor can we know if a Humphrey Court would have improved the lives of poor people. But it does not seem to me too speculative to suggest that if Humphrey had been elected, social and economic rights, American-style, would bear the same relationship to such rights in other constitutions as sex equality, Americanstyle, has to sex equality in other constitutions: Little or no difference in constitutional meaning, notwithstanding substantial difference in constitutional text.

\section{Conclusion}

Why does the American constitution lack social and economic rights? The chronological explanation contains some truth; in the late eighteenth century, such rights simply were not on the viewscreen for constitution-makers. But the chronological explanation fails for the simple reason that constitutional meaning changes over time, and chronology alone does not explain the fact that the many constitutional changes do not include recognition of social and economic rights.

The institutional explanation properly draws attention to the fact that many authors of international documents and constitutions do not think much about the question of enforcement, and attempt instead to set out goals or aspirations. American constitutionalism has generally avoided this strategy, and constitutional design, emphatically including constitutional interpretation, has been undertaken with close reference to the possibility of judicial enforcement. The problem with the institutional explanation is that social and economic rights can, in fact, coexist with judicial enforcement. There are difficulties here, but they are not insuperable.

It is tempting to think that the constitutional status of social and economic rights will be very much a function of the power, in the relevant nation, of movements for socialism or for social democracy. To some extent this is certainly true, almost a truism. But it is far from impossible to believe, enthusiastically, in a market economy, and to believe at the same time in the obligation to ensure decent conditions for everyone. The framers of the American constitution were hardly socialists, but Madison, the most important framer of all, emphasized the need for laws that would "raise extreme indigence toward a state of comfort." The New Dealers were hardly socialists, but Franklin Delano Roosevelt supported a second bill of rights, one that amounts to a match for the most expansive of social and economic rights in international documents and the modern constitutions. Many American conservatives, enthusiastic about free markets, have endorsed the idea of a social safety net for all. For these reasons, it is too crude to invoke American exceptionalism as the explanation of the absence of social and economic rights in the American constitution.

The realist explanation places a spotlight on the underappreciated fact that the United States Supreme Court came very close, in the 1960s and 1970s, to recognizing social and economic rights under the Constitution. A step of this kind would not have been fundamentally different from much of what the Court actually did in the twentieth century. Why did the Court refuse to recognize the relevant rights? A large part of the answer lies in 
the presidential election of 1968 and in particular in President Nixon's four critical appointments: Chief Justice Warren Burger and Justices Blackmun, Powell, and Rehnquist. In a very brief period in the early $1970 \mathrm{~s}$, the Court, led by these nominees, cut the ground out from an emerging movement. This, I suggest, is a real source of "American exceptionalism" in the domain of social and economic rights.

Readers with comments may address them to:

Cass R. Sunstein

University of Chicago Law School

1111 East 60th Street

Chicago, IL 60637

csunstei@midway.uchicago.edu 


\section{University of Chicago Law School \\ Public Law and Legal Theory Working Paper Series}

1. Cass R. Sunstein and Edna Ullmann-Margalit, Second-Order Decisions (November 1999; Ethics, v. 110, no. 1).

2. Joseph Isenbergh, Impeachment and Presidential Immunity from Judicial Process (November 1999; forthcoming Yale Law and Policy Review v.18 \#1).

3. Cass R. Sunstein, Is the Clean Air Act Unconstitutional? (August 1999; Michigan Law Review \#3).

4. Elizabeth Garrett, The Law and Economics of "Informed Voter" Ballot Notations (November 1999, University of Virginia Law Review, v. 85).

5. David A. Strauss, Do Constitutional Amendments Matter? (November 1999)

6. Cass R. Sunstein, Standing for Animals (November 1999)

7. Cass R. Sunstein, Culture and Government Money: A Guide for the Perplexed (April 2000).

8. Emily Buss, Without Peers? The Blind Spot in the Debate over How to Allocate Educational Control between Parent and State (April 2000).

9. David A. Strauss, Common Law, Common Ground, and Jefferson's Principle (June 2000).

10. Curtis A. Bradley and Jack L. Goldsmith, Treaties, Human Rights, and Conditional Consent (May 2000; Pennsylvania Law Review v. 149).

11. Mary Ann Case, Lessons for the Future of Affirmative Action from the Past of the Religion Clauses? (May 2001, Supreme Court Review, 2000)

12. Cass R. Sunstein, Social and Economic Rights? Lessons from South Africa (May, 2000).

13. Jill Elaine Hasday, Parenthood Divided: A Legal History of the Bifurcated Law of Parental Relations

14. Elizabeth Garrett, Institutional Lessons from the 2000 Presidential Election (May 2001).

15. Richard A. Epstein, The Allocation of the Commons: Parking and Stopping on the Commons (August 2001).

16. Jack Goldsmith, The Internet and the Legitimacy of Remote Cross-Border Searches (October 2001).

17. Adrian Vermeule, Does Commerce Clause Review Have Perverse Effects? (October 2001).

18. Cass R. Sunstein, Of Artificial Intelligence and Legal Reasoning (November 2001). 
19. Elizabeth Garrett, The Future of Campaign Finance Reform Laws in the Courts and in Congress, The William J. Brennan Lecture in Constitutional Law (December 2001).

20. Julie Roin, Taxation without Coordination (March 2002).

21. Geoffrey R. Stone, Above the Law: Research Methods, Ethics, and the Law of Privilege (March 2002; forthcoming J. Sociological Methodology 2002).

22. Cass R. Sunstein, Is There a Constitutional Right to Clone? (March 2002).

23. Emily Buss, Parental Rights (May 2002, forthcoming Virginia Law Review).

24. David A. Strauss, Must Like Cases Be Treated Alike? (May 2002).

25. David A. Strauss, The Common Law Genius of the Warren Court (May 2002).

26. Jack Goldsmith and Ryan Goodman, U.S. Civil Litigation and International Terrorism (June 2002).

27. Jack Goldsmith and Cass R. Sunstein, Military Tribunals and Legal Culture: What a Difference Sixty Years Makes (June 2002).

28. Cass R. Sunstein and Adrian Vermeule, Interpretation and Institutions (July 2002).

29. Elizabeth Garrett, Is the Party Over? The Court and the Political Process (August 2002).

30. Cass R. Sunstein, The Rights of Animals: A Very Short Primer (August 2002).

31. Joseph Isenbergh, Activists Vote Twice (November 2002).

32. Julie Roin, Truth in Government: Beyond the Tax Expenditure Budget (November 2002).

33. Cass R. Sunstein, Hazardous Heuristics (November 2002).

34. Cass R. Sunstein, Conformity and Dissent (November 2002).

35. Jill Elaine Hasday, The Principle and Practice of Women's "Full Citizenship": A Case Study of Sex-Segregated Public Education (December 2002).

36. Cass R. Sunstein, Why Does the American Constitution Lack Social and Economic Guarantees? (January 2003) 